\title{
An innovative method for creating and using nanoparticles for gas extraction from gas hydrates
}

\author{
Volodymyr Bondarenko ${ }^{1}$, Olena Svietkina ${ }^{1}$, Kostiantyn Prokopenko ${ }^{1 *}$, and Baochang Liu ${ }^{2}$ \\ ${ }^{1}$ Dnipro University of Technology, Department of Underground Mining, 19 Yavornytskoho Ave., \\ 49005 Dnipro, Ukraine \\ ${ }^{2}$ Jilin University, College of Construction Engineering, 2699 Qianjin St., 130000 Chaoyang Qu, \\ Changchun Shi, Jilin Sheng, China
}

\begin{abstract}
The growth of prices for traditional energy sources prompts Ukraine to seek new approaches to solving energy problems. Today, the country has intensified its work in this direction, in particular, legislative support is being developed and improved, and the investment climate for alternative energy projects is improving. In many countries of the world, it has long been understood how serious and necessary is the development of alternative energy. At present, in the face of various gas contradictions and unstable oil prices, the need for energy carriers is constantly increasing, which makes it necessary to seek the latest solutions to the energy problem. Many leading countries in the world are engaged in the search for alternative sources of energy, one of which is natural gas hydrates. This relatively new resource offers great opportunities both for economic growth and stability of states, and for the development of scientific institutions in this field. Flagships in the study and development of gashydrated deposits are the United States, China, Japan and Canada. Along with them should be noted the achievements of scientists in India, EU countries, Ukraine, Russia and Bulgaria.
\end{abstract}

\section{Introduction}

Given the unstable position on the gas market of Ukraine, in particular the diversification of hydrocarbon sources, it is especially important to determine the prospects for the state's energy security by increasing its own gas production. In connection with the rise in prices for oil and gas, the use of alternative types of fuel is becoming increasingly important $[1,2]$. The most commercially prepared energy carrier capable of replacing petroleum products is methane. Along with shale gas, methane from coal deposits, sandstone gas, gas condensate and other hydrocarbon sources that are found in unconventional reservoirs, gas hydrate deposits attract considerable attention [3]. The undoubted advantage of geotechnological methods of extraction of this energy raw material is the prevention of the accumulation of mining wastes on the earth's surface in comparison with classical mechanical methods of extraction [4].

\footnotetext{
*Corresponding author: npakon2536@gmail.com
} 
In nature, gas hydrates are formed in deep-sea sediments of the seas and oceans [5] and in permafrost regions - mainly from hydrocarbon gases. The most common gas contained in gas hydrates is methane. In addition to methane, other hydrocarbons (ethane, propane, butane), as well as carbon dioxide and sulphurous gases, hydrogen sulfide, argon, etc. can be part of natural gas hydrates [6].

Natural gas hydrates are ice-like crystalline compounds consisting of water molecules and natural gas. These are the so-called compound-inclusions of water molecules that are bound to each other by hydrogen bonds and form skeletons with spacious cavities inside. Chemical bonds between gas and water molecules are not formed; molecules are only contained by weak intermolecular Van-Der-Waals forces [7].

The properties of gas hydrates are unique. Thus, one volume of water in the transition to the hydrated state binds up to 200 volumes of methane. At the same time, its specific volume increases by $26 \%$ (when water freezes, its specific volume increases by $9 \%$ ). $1 \mathrm{~m}^{3}$ of methane hydrate at a pressure of 26 atm and a temperature of $0^{\circ} \mathrm{C}$, contains 164 volumes of gas. At the same time, gas accounts for $0.2 \mathrm{~m}^{3}$, water $-0.8 \mathrm{~m}^{3}$ [8].

Currently, the United States, Britain, Japan, China, Germany, Norway, Russia and others are engaged in the development of gas hydrate mining technologies. For example, the US Congress has allocated several billion dollars from the federal budget to develop gas hydrates by thermal means.

One of the objectives of the development of a gas hydrate deposit is the selection of a suitable method for the destruction of clathrate structures, based on the geological and physical features of the deposit. To date, it is possible to distinguish several basic methods of influencing a gas hydrate reservoir, all of which are based on changing equilibrium parameters such as pressure and temperature [9].

A new approach that will use the characteristics of self-heating of nickel ferrite nanoparticles $\left(\mathrm{NiFe}_{2} \mathrm{O}_{4}\right)$ to release methane from gas hydrates was presented in [10]. These nanoparticles have sizes in the range of $30-50 \mathrm{~nm}$ and, moreover, are non-toxic and environmentally friendly. Self-heating of magnetic particles is the result of hysteresis and relaxation losses, respectively [10]. For the laboratory experiment, the gas hydrate was artificially obtained using methane, and its dissociation was measured at atmospheric pressure and temperature range from -7 to $+5{ }^{\circ} \mathrm{C}$. The purpose of the experiment was to evaluate the dissociation rate and the suitability of nanotechnology for the production of methane from gas hydrates. The results showed that the self-heating temperature increased rapidly at the initial stage, and then reached a maximum. In addition, the dissociation time of the hydrate decreased when the magnetic field strength changed with a fixed frequency. In conclusion, the authors proposed a method for extracting methane from gas hydrates. The method will include nickel injection with an air suspension of ferrite nanoparticles in a gas hydrate using a horizontal injection well. The nanoparticles will pass through the cavities in the gas hydrate and get to the water cell. Then the magnetic field will be activated in the hydration zone using a magnetic tool that is located in a horizontal well. A change in the magnetic field activates the nanoparticles and causes them to raise the temperature of hydrate formations to approximately $+42^{\circ} \mathrm{C}$. Consequently, the thermodynamic equilibrium will be disturbed and this will lead to the decomposition of the water cell; eventually, methane will be released and recovered to the surface through the production well [10].

For the sequential (non-explosive) industrial destruction of clathrate compounds of gas hydrates (in order to efficiently extract the methane contained there), it is advisable to supply nanoparticles in the composition of inactive water jets in an amount corresponding to the planned number of destructible gas hydrates [11]. The main thing is their proportionality with destructible cells of clathrates - gas hydrates [12].

The efficiency of the destruction of gas hydrates also significantly depends on the shape 
of the nanoparticles, in particular, on the presence of various thorns. When a spherical particle with spikes moves along the cell surface (clathrate) of gas hydrates, the spike tip is periodically raised and lowered, which leads to the destruction of the crystal cell and the release of the methane molecule [12].

Nanostructures that look like sea urchins are quite easily formed by the electrochemical method. The main material for their construction is polystyrene [13].

In addition to spherical nanoparticles, it is more expedient to use various so-called molecular gears and axle-connected wheels as a working tool that destroys nanohydrate deposits. The shafts of gears in a similar gearbox are carbon nanotubes, and the teeth are benzene molecules [13]. At the same time, the characteristic rotational speeds of the gears are several tens of gigahertz. For the destruction of the gas hydrate cells by nanoparticles, not only the energy of the hydrodynamic flow can be used. In particular, one of the important and promising areas of application of nanotechnologies in the oil and gas industry is the creation of special miniature devices equipped with microprocessors and capable of performing targeted operations with objects of nanometer-scales called "nanorobots" [14].

According to modern theories, nano-robots should be able to perform two-way communication: respond to different signals and be able to recharge or reprogram from the outside (by means of sound or electrical oscillations) [12]. Also important are their replication functions - the self-assembly of new nano-robots and programmed selfdestruction, for example, at the end of work. In this case, robots must disintegrate into environmentally friendly and fast-acting components. Different chemical reactions, the energy of light, sound (mechanical vibrations), electromagnetic field and electric current can act as the energy of motion of nano-engines [12].

\section{Purpose and objectives of research}

The aim of the work was to obtain electromagnetic materials for nanoparticles used in the development of methane gas with a high content of hydrating gas in the solid phase.

To achieve the goal, the following tasks were set and solved:

- to establish the effect of mechanically activated additives on the process of obtaining electromagnetic nanoparticles;

- to determine the composition of the resulting materials during the mechanical activation of the mixture of materials during vibro-impact activation;

- to determine the properties of non-stoichiometric solid solutions and their influence on the process of dissociation of gas hydrates.

\section{Materials and research methods for obtaining nanoparticles with both magnetic and electrophysical properties}

\subsection{The essence of the research}

Mechanical activation of minerals was carried out at the facility, which is a laboratory MVV [15, 16], designed and manufactured at the Dnipro University of Technology (Dnipro, Ukraine). Its main advantage is the reduction of the grinding time of the powders on the one hand, and on the other - when vibro-impact activation occurs, not only the surface activation of the material, but also the violation of the internal structure of the particles. Thus, penetration of the active zone to a greater depth is observed [17], which leads to bulk ionization of the activated material. The vibration mill (Fig. 1) has two identical interchangeable grinding chambers 1 and 2 , located coaxially one above the other 
and oscillating in a vertical plane with a phase shift 180 relative to each other. The grinding chambers are connected to the frame 3 by means of elastic elements 4 . The drive is carried out by a two-shaft eccentric vibration exciter 5 mounted on the frame symmetrically with respect to the axis of the mill between the grinding chambers.

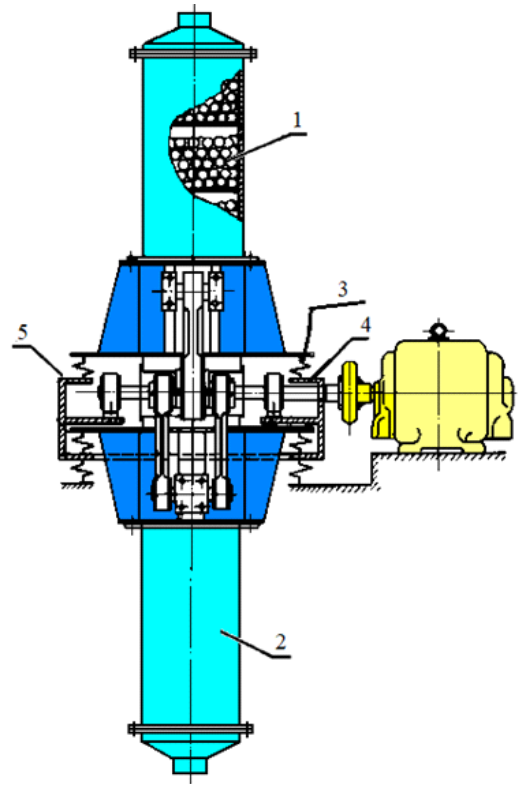

Fig. 1. Scheme mills MVV-2.

Rotation to each of the drive shafts is transmitted through elastic couplings from two electric motors. During the operation of the mill, made by a balanced scheme, dynamic loads on the base are not transferred. Therefore, installing them does not require the preparation of special foundations. When the motor is turned on, the grinding chamber performs rectilinear oscillatory movements in a vertical plane with a given amplitude $(7 \mathrm{~mm})$ and frequency $(16 \mathrm{~Hz})$. At the moments of passing the upper and lower dead points, the grinding bodies (balls made of steel SH-15) interact with each other, as well as with the bottom and the cover of the grinding chamber. Thus, the vibro-impact method of destruction is realized, in which the abrasive effect is minimal. Experiments on the mechanical activation of minerals were carried out in continuous and periodic modes, for which grinding chambers of different designs were used. In continuous mode, the material from the feed hopper enters the grinding chamber, passes the path $L$ and then goes to the receiving bin. The value of $L$ is determined by the height of the grinding chamber and the number of passes through it of material. In the periodic mode, the sample of the material is poured into the chamber, hermetically closed in it and the specified time is ground. At the same time the mass of a portion of the crushed material is recorded.

In the periodic mode, the material being crushed is poured into the chamber previously. To eliminate environmental pollution, the chamber lid is hermetically closed. When the motor is turned on, the grinding chamber performs rectilinear oscillatory movements in a vertical plane with a given amplitude $(7 \mathrm{~mm})$ and frequency $(16 \mathrm{~Hz})$. At the moments of passing the upper and lower dead points, the grinding bodies interact with each other, as well as with the bottom and the cover of the grinding chamber.

An important factor affecting the efficiency of the grinding process in the MVV mill is the gap between the upper layer of the balls and the cover of the grinding chamber, which 
depends on the degree of filling of the chamber with balls. As a result of preliminary tests, it was found that for diameters of balls of 6 and $9 \mathrm{~mm}$, the maximum energy intensity of the process load occurs when $\Delta=9-20 \mathrm{~mm}$ and weakly depends on the total height of the layer of balls in the chamber. Laboratory studies were carried out in two stages. At the first stage, the most rational technological parameters of grinding were determined, which made it possible to obtain the best result in terms of the specific surface area. During the experiment, the diameter of the grinding bodies and the mass ratio of the material to be ground and the process load were varied. The grinding bodies were balls with a diameter of $6 \mathrm{~mm}$ and $9 \mathrm{~mm}$. The gap between the balls and the lid of the chamber in all experiments was $10 \mathrm{~mm}$. The mass of portions of the crushed material $\mathrm{m}$ was $1 / 20$ and $1 / 40$ of the mass of the balls $\mathrm{m}$. After a certain period of time, samples of the powder were taken, which were observed under a microscope to study the shape of the particles and assess the particle size distribution of the material obtained. In each case, the chambers were opened only after they cooled down to room temperature. After examination under a microscope, samples of the powder were returned to the chambers for further grinding. Thus, the diameter of the balls $d_{b}$ was established, at which the most efficient grinding of materials took place. The influence of the parameter $m_{m} / m_{b}$ on the particle size distribution of the grinding product was not visually assessed. To clarify the data obtained, experiments were carried out using technical methods of laboratory analysis.

The adopted diameter of the grinding bodies was used in the following experiment, in which only the mass ratio of the material to be ground and the process load was changed. Here, in addition to visual observation, the specific surface area was also measured. The maximum ratio of the mass of the powder to the mass of the balls $m_{p} / m_{b}$ was determined from the maximum value of the specific surface area $S_{s}$.

To establish the dispersion constant, a method was used to estimate the particle size distribution of powders on a specific surface, which is a convenient dispersion characteristic. The specific surface area was determined by the rarefied gas filtration resistance. The method is based on the developed B.N. Deryagin's theory of the flow of rarefied gas through a system of solid balls, when the path length of gas molecules is much longer than the distance between the balls (Knudsen flow regime) [18]. The accuracy of the method is $1 \%$.

The average size of the crushed particles was determined according to the data obtained on a SK LAZER MICRON SIZER PRO-700 laser analyzer (Japan). The formation of an activated state is closely related to the energy characteristics of the material. In this connection, a universal method was used to study the energy characteristics of materials by potentiometric measurements in suspensions with an indiderent electrode. The method of potentiometric measurements [19] allows to calculate the potential curve and the total adsorption potential.

In situ diffractograms were obtained on a DRON-2 X-ray diffractometer (Burevestnik, Russia). The phase analysis of the materials was determined on an X-ray diffractometer DRON-3 (Burevestnik, Russia): Fe Ka radiation, high voltage $35 \mathrm{eV}$, anode current $20 \mathrm{~mA}$. The physicochemical processes occurring during the production of methane gas hydrate were studied using the methods of differential thermal analysis (DTA) and X-ray fluorescence analysis (XRF). The composition of the gaseous products was investigated by gas adsorption chromatography on an LHM-2000-TM chromatograph (Elektra, Russia).

\subsection{The method of obtaining mechanically activated nanoparticles, as well as the study of the process of dissociation of gas hydrate in their presence}

Synthesis of methane gas hydrate was carried out in an apparatus for the production of gas hydrates, which makes it possible to simulate thermobaric conditions similar to natural ones [20]. The NPO-5 (Fig. 2) installation, designed at NGU, allows to conduct studies of the 
high-speed production of methane gas in "mild" conditions, varying the temperature (from +0.5 to $+10^{\circ} \mathrm{C}$ ) and pressure (from 1 to $10 \mathrm{MPa}$ ) [21, 22]. Further, in accordance with the previously developed method [23], the process of producing methane gas hydrate began.

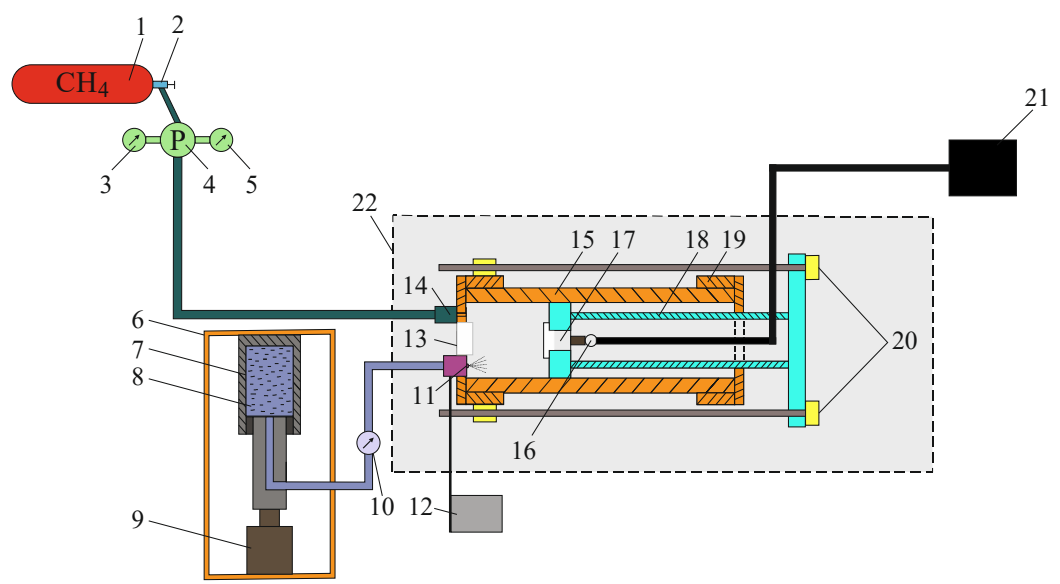

Fig. 2. Laboratory unit NPO-5 for the production of gas hydrates: 1 - methane cylinder; 2 - cylinder valve; 3 - high pressure gauge; 4 - adjustable gear; 5 - low pressure gauge; 6 - rigid frame; 7 - a device for creating water pressure; 8 - water; 9 - hydraulic jack; 10 - water pressure gauge; 11 - electric water injection nozzle; 12 -pulse generator for the nozzle; 13 - transparent reactor window; 14 - gas inlet fitting; 15 - hydrate formation reactor; 16 - LED block; 17 - transparent stock window; 18 - stock; 19 the directing flange; 20 - coupling bolts with nuts; 21 - battery for power; 22 - refrigerator.

The process of gas dissociation was carried out in the installation shown in Fig. 3 according to the following method:

1. After the end of the process of obtaining gas hydrate (when all the water reacted), the temperature in the climatic thermocamera, and accordingly in the hydrate formation reactor, was reduced from +1 to $-15^{\circ} \mathrm{C}$. The process of hydrate formation in the reactor was observed through the window in the chamber and the reactor.

2. Shut off the valves on the gas cylinder and on the gearbox.

3. The high pressure hose was disconnected from the gearbox and connected to a gas meter.

4. The reactor valve was opened and the temperature in the chamber and the reactor was raised to room temperature.

5. Methane hydrate began to decompose. The released methane passed through the gas meter and its amount was determined.

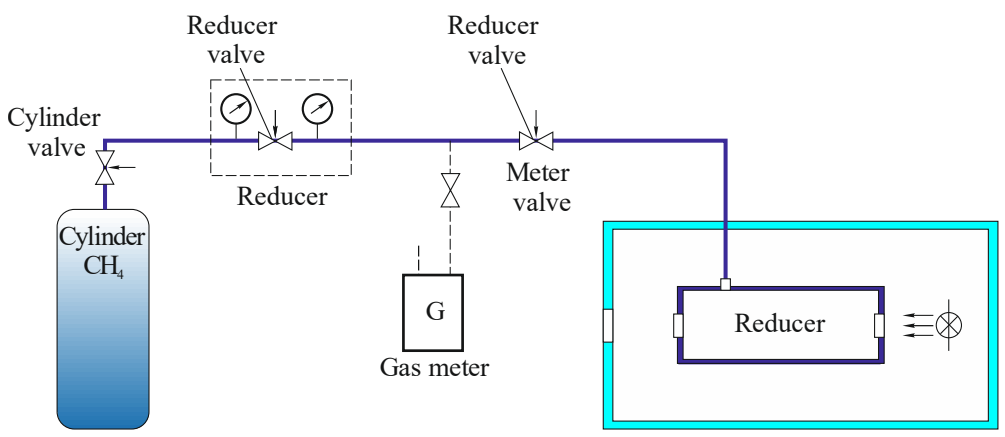

Fig. 3. Experimental setup. 
Knowing the magnitude of the gas emitted and the volume of water poured into the reactor, the value of $\mathrm{cm}$ was calculated. Then the gas pressure in the reactor was reduced by $1 \mathrm{MPa}$ and the process was repeated. The composition of the resulting gas was determined by chromatography.

\section{Results and discussion}

In recent years, there has been an increased interest in nanoparticles with "special" properties, i.e. which sometimes even contradict the properties of the same substance in the macrostate. Unusual chemical and physical properties show solids mechanically activated in various shredders [24]. One of the reasons is the manifestation of the so-called "quantum size effects", which are related to the fact that the transition from a macroscopic to a microscopic state in the valence band and in the conduction band drastically changes the density of states, which is caused by the behavior of electrons, usually magnetic and electrical [25].

Mechano-chemical activation of materials was carried out in a vertical vibration mill, the main advantage of which is the vibro-impact effect on the material being destroyed. High energy intensity of the internal volume of the grinding chamber reduces the time of grinding powders. As a rule, mechanical activation occurs at the moment of chemical processing of the material not everywhere, but mainly where stresses are concentrated at the point of contact between solid particles, where chemical processes occur due to local heat generation and the simultaneous occurrence of rather high pressures and shear stresses in this region of the crystal [26].

Vibro-shock loading of the crushed material allows not only the surface shear, but also affects the particles with the penetration of the deformation zone over the entire volume of it. This provides not only the surface activation of the material, but also a violation of the internal structure of the particles and the penetration of the active zone to a greater depth [27].

Solving the problems of the formation of mechanically activated states opens up new possibilities for solid-phase synthesis of new materials with desired properties, in particular, the creation of high-density polycrystalline ceramics with the highest conductivity, mechanical strength and chemical and thermal stability.

In the process of vibro-impact, powder-like emitters are formed, which are sources of special-purpose ions. Moreover, the activated states thus obtained are emitters with a high current stability in time and the possibility of obtaining ion currents with different densities.

In connection with the above, we conducted studies on the joint grinding of feldspar and oxidized quartzites, in particular, the conduct of solid-phase synthesis:

$$
\begin{aligned}
& \mathrm{FeO}+2 \mathrm{Al}_{2} \mathrm{O}_{3}+\mathrm{K}_{2} \mathrm{O} \rightarrow \mathrm{FeAl}_{2} \mathrm{O}_{4}+\mathrm{K}_{2} \mathrm{Al}_{2} \mathrm{O}_{4} \\
& \mathrm{FeAl}_{2} \mathrm{O}_{4}+\mathrm{Fe}_{2} \mathrm{O}_{3} \rightarrow \mathrm{Fe}_{3} \mathrm{O}_{4}+\mathrm{Al}_{2} \mathrm{O}_{3} .
\end{aligned}
$$

The resulting mixed crystals grow much more slowly even with increasing temperature, i.e. Feldspar is not only an electron type promoter, due to a change in the crystal lattice during loading and volume ionization, but also a constituent modifier $\mathrm{Al}_{2} \mathrm{O}_{3}$ that prevents surface deactivation and recrystallization $\alpha-F e$ into inactive conglomerates. One of the sources $\alpha-F e$ is goethite [28].

For these studies used oxidized quartzite and feldspar, the chemical composition of which is presented in Tables 1 and 2.

The source material was fraction -50 microns. Table 3 presents data on the particle size distribution during vibration impact activation. 
Table 1. The chemical composition of oxidized quartzite, wt.\%.

\begin{tabular}{|c|c|c|c|c|c|c|c|c|}
\hline $\mathrm{FeO}$ & $\alpha-\mathrm{Fe}_{2} \mathrm{O}_{3}$ & $\mathrm{SiO}_{2}$ & $\mathrm{Al}_{2} \mathrm{O}_{3}$ & $\mathrm{CaO}$ & $\mathrm{MgO}$ & $\mathrm{MnO}$ & $\mathrm{P}_{2} \mathrm{O}_{5}$ & $\mathrm{~S}$ \\
\hline 3.4 & 52.7 & 43.5 & 0.32 & 0.18 & 0.85 & 0.026 & 0.047 & 0.013 \\
\hline
\end{tabular}

Table 2. Chemical composition of feldspar.

\begin{tabular}{|c|c|c|c|c|}
\hline \multirow{2}{*}{ Components } & \multicolumn{2}{|c|}{ Orthoclass } & \multirow{2}{*}{$\mathrm{K}_{2} \mathrm{O}$} & \multirow{2}{*}{$\mathrm{Na}_{2} \mathrm{O}$} \\
\cline { 2 - 3 } & $\mathrm{SiO}_{2}$ & $\mathrm{Al}_{2} \mathrm{O}_{3}$ & & 0.5 \\
\hline Containing \% & 65.7 & 18.7 & 15.1 & 0.1 \\
\hline
\end{tabular}

Table 3. Results of the activation of a mixture of minerals.

\begin{tabular}{|c|c|c|c|c|c|}
\hline$t$, min & initial & 10 & 20 & 30 & 40 \\
\hline Average particle size, microns & 9.6 & 6.9 & 3.5 & 2.9 & 1.5 \\
\hline
\end{tabular}

The second stage of our work was the study of changes in the properties of iron ore under vibro-impact loading. Iron oxide is of particular interest from a scientific and practical point of view, since the amount of energy contained in the aggregate of oxygen in the gland differs from the energy contained in its various structures. Various physical and chemical changes and transformations of substances consist primarily of changes in the amount of stored energy in crystalline structures [29].

When feldspar in the amount of $8 \%$ is added to the oxidized quartzites as the loading increases, the formation of goethite is observed, and then when feldspar is added in the amount of $16 \%$, magnetite $\left(\mathrm{Fe}_{2} \mathrm{O}_{3}\right)$ appears. Vibro-impact activation was performed under non-isometric conditions until the corresponding effects on DTA were completed. In Fig. 4 shows the X-ray spectrum [30].

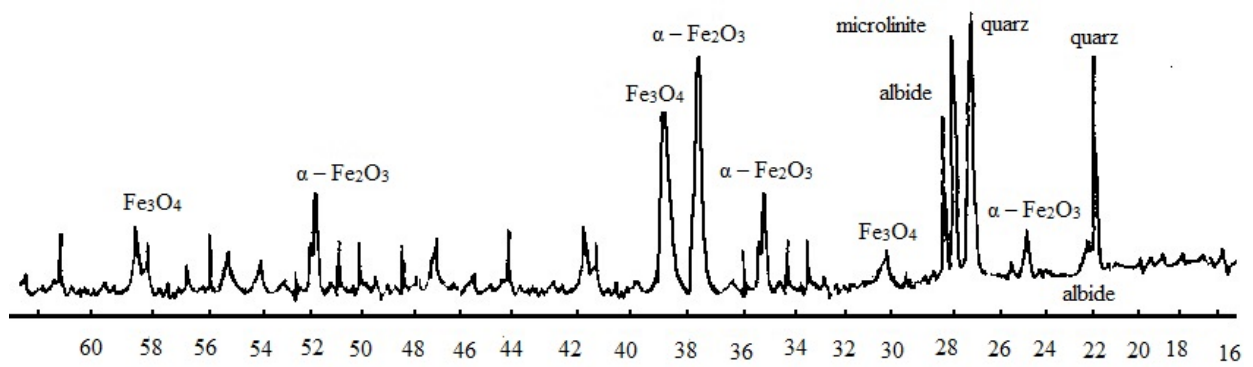

Fig. 4. X-ray spectrum analysis of joint vibro-impact activation of feldspar and oxidized quartzite within 10 minutes.

The radiograph of the product vibro-impact activation contains broad lines: goethite.

On the radiograph activated for 10 minutes by vibro-shock loading of samples containing $8 \%$ feldspar, there are lines of goethite and $\alpha-\mathrm{Fe}_{2} \mathrm{O}_{3}$. Moreover, there is a decrease in the relative intensity and an increase in their width with an increase in the content of goethite in mixtures. Thus, the observed effect leads to the following conclusions:

1. Field spar, which has a lower hardness, transforms into X-ray amorphous states with a loose $\mathrm{Al}-\mathrm{O}-\mathrm{Si}$ network, and thus protects goethite from destruction and transformation into $\alpha-\mathrm{Fe}_{2} \mathrm{O}_{3}$.

2. In the process of joint vibro-impact loading of oxidized quartzites and feldspar, a 
structure of the "packing defect" type is loaded, which is experimentally detected by the broadening of lines on the radiograph.

3. Surface and volume joint ionization of feldspar and oxidized quartzite leads to catalytic phenomena with respect to the transition and $\alpha-\mathrm{Fe}_{2} \mathrm{O}_{3} \rightarrow \mathrm{Fe}_{3}$ getite $\rightarrow \mathrm{Fe}_{3} \mathrm{O}_{4}$.

In further studies on joint vibration impact on a mixture of oxidized quartzites and feldspar, it turned out that at $16 \%$ feldspar peaks corresponding to $\mathrm{Fe}_{3} \mathrm{O}_{4}$ appear.

Table 4 presents the results of kinetic studies associated with the formation of magnetite $\left(\mathrm{Fe}_{3} \mathrm{O}_{4}\right)$.

Table 4. Kinetics of the formation of magnetite during vibro-impact activation of oxidized quartzites.

\begin{tabular}{|c|c|c|c|c|c|c|}
\hline Time of vibration impact loading, $t$ min. & 0 & 5 & 10 & 15 & 20 & 30 \\
\hline$\%$ Content of $\mathrm{Fe}_{3} \mathrm{O}_{4}$. & 0 & 0.8 & 2.5 & 6.0 & 9.2 & 9.5 \\
\hline
\end{tabular}

In Fig. 5 shows the concentration curves corresponding to this process. Dependence is extreme. The product of vibro-impact activation of oxidized quartzites and feldspar was investigated using the DTA method [31].

It turned out that goethite in the presence of catalytic amounts of feldspar is dehydrated at temperatures below $3000{ }^{\circ} \mathrm{C}$. As a result, the ferric iron ions present in it are immediately reduced to amorphous $\mathrm{Fe}_{3} \mathrm{O}_{4}$, which in turn recrystallizes into magnetite in the temperature range $300-3600{ }^{\circ} \mathrm{C}$.

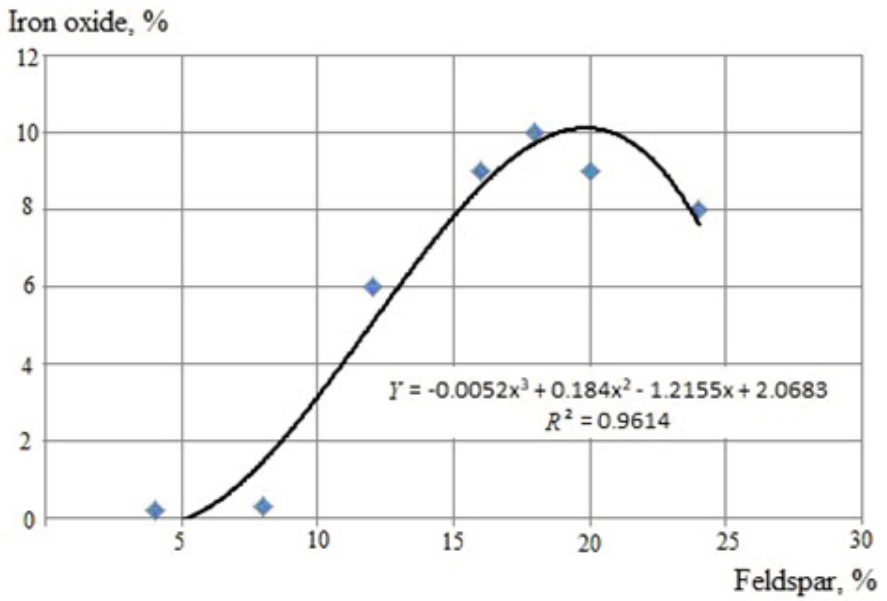

Fig. 5. The concentration dependence of the formation of magnetite on the concentration of feldspar.

It should be noted that during vibro-impact on the oxidized quartzites, goethite is oxidized mainly to maghelite $\left(\gamma-\mathrm{Fe}_{2} \mathrm{O}_{3}\right)$, and then at $775-8360{ }^{\circ} \mathrm{C}$ a transition of $\gamma-\mathrm{Fe}_{2} \mathrm{O}_{3}$ to $\alpha-\mathrm{Fe}_{2} \mathrm{O}_{3}$ is observed, besides solid solutions are formed under vibro-impact loading.

The catalytic feature of feldspar is in the volume ionization of potassium ions and their participation in a chemical reaction according to equations 1.

These results show that each of the considered iron oxides $\left(\mathrm{Fe}_{3} \mathrm{O}_{4}\right.$ and $\left.\alpha-\mathrm{Fe}_{2} \mathrm{O}_{3}\right)$ can change the composition, approaching one or even two other oxides, without significant breaking of the structure, but only due to the redistribution of ions between tetrahedral and octahedral voids.

Thus, there is a change in the oxygen index at the transition of the octahedral structure, characteristic of $\alpha-\mathrm{Fe}_{2} \mathrm{O}_{3}$, to the structure of the "reverse" spinel, which is characteristic of $\mathrm{Fe}_{3} \mathrm{O}_{4}$. 
Numerous studies have established [23] that there are defects in the oxygen sublattice, and their different ordering determines the superconducting properties of the material, the beginning of the removal of weakly bound oxygen, and the transition temperature of the octahedral phase to inverse spinel. The main influence on the change in critical temperature has an oxygen content. The reaction of the microscopic ordering of oxygen includes the processes of nucleation and the growth of domains of a certain symmetry within one phase. These domains are usually extended in a certain direction and then under the action of temperature at the moment of impact during vibro-impact loading they are rearranged in the microregion (some micropackages) of thin plates within the whole structure, and the plates are oriented along the plane. The model is well supported by experimental data on the observation of the mutual germination of the structures of both phases.

The following experimental studies were carried out for the $\mathrm{Fe}_{2} \mathrm{O}_{3}-\mathrm{Al}_{2} \mathrm{O}_{3}$ system: comparisons of the electrical and X-ray phase characteristics of complex spinel systems. Such systems are obtained by vibro-impact loading with joint grinding of oxidized ores and feldspar or hydrargillite [32].

In Fig. 6 shows the dependence of the electrical conductivity of the oxidized quartzite feldspar system on the bulk composition and time of vibro-impact loading.

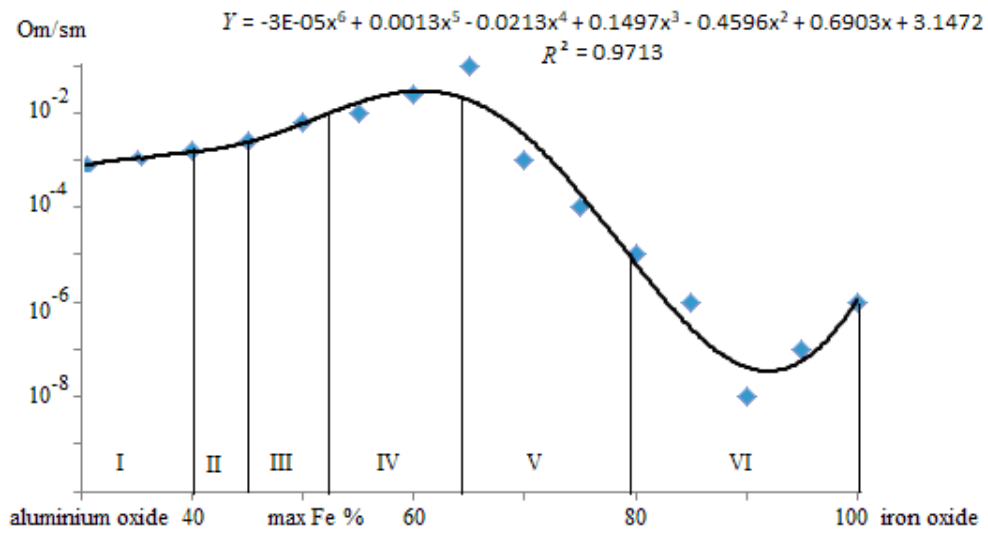

Fig. 6. Dependence of the electrical conductivity of the system $\mathrm{Fe}_{2} \mathrm{O}_{3}-\mathrm{Al}_{2} \mathrm{O}_{3}$ on the volumetric composition determined by X-ray.

$\mathrm{X}$-ray phase analysis showed the following composition of phase areas:

$\mathrm{I}-$ mixture of $\mathrm{Fe}_{2} \mathrm{O}_{3}+\beta$ getite.

II - solid solution of $\mathrm{FeAl}_{2} \mathrm{O}_{4}$ in $\mathrm{Fe}_{1}-\mathrm{O}_{\mathrm{x}}$.

III - spinel solution of $\mathrm{FeAl}_{2} \mathrm{O}_{4}$ in magnetite.

$\mathrm{IV}$ - two solid solutions of normal and reversed spinel $\mathrm{FeAl}_{2} \mathrm{O}_{4}$.

$\mathrm{V}$ - solid solution of $\mathrm{Al}_{2} \mathrm{O}_{3}$ in tetragonal spinel $\mathrm{FeAl}_{2} \mathrm{O}_{4}$.

$\mathrm{VI}-\mathrm{FeAl}_{2} \mathrm{O}_{4}$ solid solution in $\mathrm{Al}_{2} \mathrm{O}_{3}$.

So, with vibro-impact activation of minerals, a change in electrical conductivity is observed not only due to the shift of the Fermi level as a result of the appearance of bulk and surface defects (structural and chemical) with the introduction of the second component, but also due to the formation of a new phase - a solid solution or chemical compound as a product of the interaction of the components system.

In this perspective, one can consider the change in the magnetic moment of the mixture during the vibro-impact activation of oxidized quartzites with alumino-silicates. This is due to phase transitions in solids, as a result of which the structures of the two phases are close, and one sublattice can be transformed into another. However, in the series of phase 
transitions, when the characteristic features of the atomic distribution remain unchanged, there are order-disorder transitions. An example of such a transition can serve as transitions due to the disordering in orientation of positively charged particles and their slightly distorted environment in spinels containing asymmetric transition metal ions. On the other hand, as a result of vibro-shock loading, ordering of $\mathrm{Fe}^{2+}$ and $\mathrm{Fe}^{3+}$ ions (ie, electrons) can occur in the b-sites of ferrous oxide with iron, which leads to a low conductivity of this compound, which makes it difficult to further release magnetite from iron ores.

Solid solutions of normal iron aluminate $\left(\mathrm{FeAl}_{2} \mathrm{O}_{4}\right)$ with reversed magnetite are formed throughout the concentration range. They form the basis of spinelide - the mineralogical component of aluminum slag. The physical, physicochemical, and thermodynamic properties of such solid solutions are not well understood [33].

Statistical-thermodynamic analysis of binary spinel solutions has shown that the activities of simple spinels selected for the components depend both on the composition and the degree of inversion $\lambda$ (parameter showing the quantitative distribution of cations over the tetrahedral and octahedral interstices of the crystal spinel lattice). In this paper, [12], a method for determining the electrical activity of simple spinels in a binary solid solution is proposed.

Summarizing the results obtained, on the basis of the proposed model, we can conclude that the transition from $\alpha-\mathrm{Fe}_{2} \mathrm{O}_{3}$ to $\mathrm{Fe}_{3} \mathrm{O}_{4}$ and then to $\mathrm{Fe}$ in a good approximation is interpreted as a thermoelastic martensitic transformation in equilibrium with air oxygen. The introduction of ionized potassium ions with the joint grinding of two minerals redistributes the ratio of the low-temperature and high-temperature phases:

(goethite $\rightarrow \mathrm{Fe}_{3} \mathrm{O}_{4}$ ) (goethite $\rightarrow \alpha-\mathrm{Fe}_{2} \mathrm{O}_{3}$ ). The ratio in the mixture of phases is in the presence of $\mathrm{K}^{+}, \mathrm{Na}^{+}$ions in favor of the low-temperature phase. Thus, the above experiments confirm the existence of additional surface and volume ionization under vibroimpact loading of minerals, in particular, oxidized quartzites and feldspar. From the obtained particles, nanoclusters were obtained by the method of [24].

The rate of hydrate formation of methane in the presence of nanoclasters was determined by the kinetic method from the initial rate of icy crust formation, and then the amount of methane per unit volume $\left(C_{m}\right)$ was determined at various surfactant contents.

Measuring the volume of methane from gas hydrate is possible to determine in two ways:

- first, by measuring the volume of gas entering the reactor at a high pressure, but this method is very difficult, since there are no meters that measure a small amount of gas passing through at a high pressure;

- the second, by measuring the volume of gas leaving the reactor during the decomposition of the hydrate; in this case, the pressure is low, which allows the use of domestic gas meters operating at a pressure of less than $1 \mathrm{MPa}$.

In Fig. 2 shows the experimental setup, where dissociation of gas hydrates of various compositions was carried out under various conditions of their formation and the subsequent study of the obtained samples.

The following methodology was developed to determine $C_{m}$ :

1. After the end of the process of obtaining gas hydrate (all the water reacted), the temperature in the climatic thermocamera and, accordingly, in the hydrate formation reactor decreased from 274 to $263-258 \mathrm{~K}$. The process of hydrate formation in the reactor was observed through the window in the chamber and the reactor.

2. Shut off the valves on the gas cylinder and on the gearbox. We sprayed nanoclusters.

3. The high pressure hose was disconnected from the gearbox and connected to a gas meter.

4. The reactor valve was opened and the temperature in the chamber and the reactor was raised to room temperature. 
5. Methane hydrate begins to decompose. Allocated methane passes through the gas meter and its quantity is determined.

The $C_{m}$ value was determined to determine the completeness of gas hydrate dissociation and the time of dissociation. Then the gas pressure in the reactor was reduced by $1 \mathrm{MPa}$ and the determinations were repeated.

Experimental data are presented in Table 5.

Table 5. The results of the studies of the dissociation of gas hydrate.

\begin{tabular}{|c|c|c|}
\hline \multirow{2}{*}{ Dissociation time, $\mathrm{s}$} & \multicolumn{2}{|c|}{ Conditions of dissociation gas hydrate } \\
\cline { 2 - 3 } & Without nanoclusters & With nanoclusters \\
\cline { 2 - 3 } & 120 & 60 \\
\hline Volume of methane, mol & 4 & 4 \\
\hline
\end{tabular}

Thus, the dissociation time of gas hydrate is reduced almost by half. In the presence of nanoclusters, complete dissociation occurs.

\section{Conclusions}

For the first time, vibro-impact activation of materials was used, during which solid solutions with electrophysical properties are formed.

Nanoclusters have been obtained that can be regenerated not only due to magnetic fields, but also due to electric.

The composition of nanoclusters includes natural minerals corresponding to the bottom composition, which is environmentally acceptable, containing cobalt compounds.

It is shown that the time of gas hydrate reactivation is accelerated, and the process can be regelled due to concentration dependencies.

This work has been performed in the framework of tasks of a research project funded by the state budget by the Ministry of Education and Science of Ukraine "Detection of regularities of phase transformations of gas hydrates and stressed-strain state of a rock massif and development of innovative geotechnologies".

\section{References}

1. Lozynskyi, V., Saik, P., Petlovanyi, M., Sai, K., Malanchuk, Z., \& Malanchuk, Y. (2018). Substantiation into mass and heat balance for underground coal gasification in faulting zones. Inzynieria Mineralna, 19(2), 289-300. https://doi.org/10.29227/IM-2018-02-36

2. Bondarenko, V., Lozynskyi, V., Sai, K., \& Anikushyna, K. (2015). An overview and prospectives of practical application of the biomass gasification technology in Ukraine. New Developments in Mining Engineering 2015: Theoretical and Practical Solutions of Mineral Resources Mining, 2732. https://doi.org/10.1201/b19901-6

3. Bondarenko, V.I., Kharin, Ye.N., Antoshchenko, N.I., \& Gasyuk, R.L. (2013). Basic scientific positions of forecast of the dynamics of methane release when mining the gas bearing coal seams. Naukovyi Visnyk Natsionalnoho Hirnychoho Universytetu, (5), 24-30.

4. Petlovanyi, M., Kuzmenko, O., Lozynskyi, V., Popovych, V., \& Sai, K. (2019). Review of manmade mineral formations accumulation and prospects of their developing in mining industrial regions in Ukraine. Mining of Mineral Deposits, 13(1), 24-38. https://doi.org/10.33271/mining13.01.024

5. Bondarenko, V., Maksymova, E., \& Koval, O. (2013). Genetic classification of gas hydrates deposits types by geologic-structural criteria. Annual Scientific-Technical Colletion - Mining of Mineral Deposits, 115-119. https://doi.org/10.1201/b16354-21 
6. Makogon, Y.F., \& Makogon, T.Y., (n.d.). Natural gas hydrates. Exploration and Production of Petroleum and Natural Gas, 429-459. https://doi.org/10.1520/mn17320140017

7. Carroll, J. (2014). Hydrate types and formers. Natural Gas Hydrates, 23-57. https://doi.org/10.1016/b978-0-12-800074-8.00002-8

8. Boswell, R. (2009). Is gas hydrate energy within reach? Science, 325(5943), 957-958. https://doi.org/10.1126/science.1175074

9. Bondarenko, V., Svietkina, O., \& Sai, K., (2017). Study of the formation mechanism of gas hydrates of methane in the presence of surface-active substances. Eastern-European Journal of Enterprise Technologies, 5(6(89)), 48-55. https://doi.org/10.15587/1729-4061.2017.112313

10. Bhatia, K.H., \& Chacko, L.P., (2011). A novel approach to recover hydrates using Ni-Fe nanoparticles. SPE EUROPEC/EAGE Annual Conference and Exhibition. https://doi.org/10.2118/143088-ms

11. Bondarenko, V., Svietkina, O., Sai, K., \& Klymenko, V. (2018). Investigation of the influence of polyelectrolytes hydrodynamic properties on the hydrateformation process. E3S Web of Conferences, (60), 00007. https://doi.org/10.1051/e3sconf/20186000007

12. Vorob'yev, A.E., (2018) Dissociation of gas hydrates in frozen sands: effect on gas. Earth's Cryosphere, (1). https://doi.org/10.21782/ec2541-9994-2018-1(41-45)

13. Vorob'yev, A.E., (2016). Prospects of nanotechnologies of developing gaseous-hydrate resources of the Russian Arctic shelf. Vestnik MGTU, 19(1/1), 70-81. http://doi.org/10.21443/1560-92782016-1/1-70-81

14. Bondarenko, V.I., \& Sai, K.S. (2018). Process pattern of heterogeneous gas hydrate deposits dissociation. Naukovyi Visnyk Natsionalnoho Hirnychoho Universytetu, (2), 21-28. http://doi.org/10.29202/nvngu/2018-2/4

15. Ganushevych, K., Sai, K., \& Korotkova, A. (2014). Creation of gas hydrates from mine methane. Progressive Technologies of Coal, Coalbed Methane, and Ores Mining, 505-509. http://doi.org/10.1201/b17547-85

16. Franchuk, V.P., (1995). Opredelenie temperatury v zone nagruzheniya pri vibroudarnom nagruzhenii. Teoriya i praktika protsessov izmel'cheniya i razdeleniya, 15-23.

17. Franchuk, V.P., (2010). Vibratsionnaya tekhnika v malykh proizvodstvakh. Heotekhnichna Mekhanika, (85), 290-296.

18. Svietkina, O., Bas, K., Alfaqs, F., Ziborov, K., \& Fedoskin, V. (2019). Mechanochemical Activation of Materials to Produce Conductive and Superconductive Substances for Batteries. Solid State Phenomena, (291), 121-130. https://doi.org/10.4028/www.scientific.net/ssp.291.121

19. Svietkina, O. (2013). Receipt of coagulant of water treatment from radio-active elements. Annual Scientific-Technical Collection - Mining of Mineral Deposits, 227-230. https://doi.org/10.1201/b16354-42

20. Korsakov, V.G., Shelomentseva, I.V., Yur'yevskaya, I.M., \& Petrova, L.I., (1983). Issledovanie energeticheskikh kharakteristik i prognozirovanie fiziko-khimicheskikh i tekhnicheskikh svoystv materialov. Napravlennyy Sintez Tverdykh veshchestv, (1), 158-174.

21. Bondarenko, V., Svietkina, O., \& Sai, K., (2018). Effect of mechanoactivated chemical additives on the process of gas hydrate formation. Eastern-European Journal of Enterprise Technologies, 1(6(91)), 17-26. https://doi.org/10.15587/1729-4061.2018.123885

22. Ovchynnikov, M., Ganushevych, K., \& Sai, K. (2013). Methodology of gas hydrates formation from gaseous mixtures of various compositions. Annual Scientific-Technical Colletion - Mining of Mineral Deposits, 203-205. https://doi.org/10.1201/b16354-37

23. Bondarenko, V., Ganushevych, K., Sai, K., \& Tyshchenko, A. (2011). Development of gas hydrates in the Black sea. Technical and Geoinformational Systems in Mining: School of Underground Mining, 55-59. https://doi.org/10.1201/b11586-11

24. Bondarenko, V., Kovalevska, I., Astafiev, D., \& Malova, O. (2018). Examination of phase transition of mine methane to gas hydrates and their sudden failure - Percy Bridgman's Effect. Solid State Phenomena, (277), 137-146. https://doi.org/10.4028/www.scientific.net/ssp.277.137 
25. Li, S., Han, Z., Meng, Q., Zhao, X., Cao, X., \& Liu, B., (2018). Effect of WC nanoparticles on the microstructure and properties of WC-bronze-Ni-Mn based diamond composites. Applied Sciences, 8(9), 1501. https://doi.org/10.3390/app8091501

26. Khomutov, G.B., \& Koksharov, Y.A., (n.d.). Organized ensembles of magnetic nanoparticles: preparation, structure, and properties. Magnetic Nanoparticles, 117-195. https://doi.org/10.1002/9783527627561.ch5

27. Zhuang, S., Lee, E. S., Lei, L., Nunna, B. B., Kuang, L., \& Zhang, W. (2016). Synthesis of nitrogen-doped graphene catalyst by high-energy wet ball milling for electrochemical systems. International Journal of Energy Research, 40(15), 2136-2149. https://doi.org/10.1002/er.3595

28. Sun, Y., Yu, Y., Wu, B., \& Liu, B., (2016). Closed form solutions for nonlinear static response of curled cantilever micro-/nanobeams including both the fringing field and van der Waals force effect. Microsystem Technologies, 23(1), 163-174. https://doi.org/10.1007/s00542-016-2870-y

29. Sun, Y., Meng, Q., Qian, M., Liu, B., Gao, K., Ma, Y., \& Zheng, W. (2016). Enhancement of oxidation resistance via a self-healing boron carbide coating on diamond particles. Scientific Reports, 6(1). https://doi.org/10.1038/srep20198

30. Sai, K., Malanchuk, Z., Petlovanyi, M., Saik, P., \& Lozynskyi, V. (2019). Research of Thermodynamic Conditions for Gas Hydrates Formation from Methane in the Coal Mines. Solid State Phenomena, (291), 155-172. https://doi.org/10.4028/www.scientific.net/SSP.291.155

31. Gao, K., Li, M., Dong, B., Sun, Y., \& Liu, J. (2014). Bionic coupling polycrystalline diamond composite bit. Petroleum Exploration and Development, 41(4), 533-537. https://doi.org/10.1016/s1876-3804(14)60063-x

32. Dishlyuk, L., Novoselova, M., \& Rozalyonok, T. (2013). Immobilization of chymotrypsin on magnetic $\mathrm{Fe}_{3} \mathrm{O}_{4}$ nanoparticles. Foods and Raw Materials, 1(2), 85-88. https://doi.org/10.12737/2060

33. Bondarenko, V., Sai, K., Prokopenko, K., \& Zhuravlov, D. (2018). Thermodynamic and geomechanical processes research in the development of gas hydrate deposits in the conditions of the Black Sea. Mining of Mineral Deposits, 12(2), 104-115. https://doi.org/10.15407/mining12.02.104 